\title{
DANA PERIMBANGAN DALAM PEMBAGIAN URUSAN PEMERINTAHAN PUSAT DAN DAERAH
}

\author{
Abd. Rais Asmar \\ Universitas Negeri Islam (UIN) Alauddin Makassar \\ Email: rais.asmar@uin-alauddin.ac.id
}

\begin{abstract}
The issue of balancing funds which is a potential source of revenue for the regions is closely related to the central and regional governmental affairs because the funds are sourced from the state budget. Balancing Funds are funds sourced from APBN revenues allocated to regions to fund local needs in the context of decentralization implementation. The current DBH allocation is too complex as it lacks a strong foundation and varies the basis of assignment for revenue sharing. The DBH distribution mechanisms in the regions also often experience delays.
\end{abstract}

Keywords: Balancing Fund

\begin{abstract}
Abstrak
Permasalahan dana perimbangan yang menjadi sumber penerimaan potensial bagi daerah berhubungan erat dengan pembagian urusan pemerintahan pusat dan daerah karena dananya bersumber dari APBN. Dana Perimbangan adalah dana yang bersumber dari pendapatan APBN yang dialokasikan kepada daerah untuk mendanai kebutuhan daerah dalam rangka pelaksanaan desentralisasi. Alokasi DBH saat ini terlalu komplek seperti kurang memiliki landasan yang kuat dan beragamnya dasar penetapan untuk bagi hasil. Mekanisme penyaluran DBH di daerah juga sering mengalami keterlambatan.
\end{abstract}

Kata Kunci: Dana Perimbangan

Jurisprudentie | Volume 4 Nomor 2 Desember 2017 


\section{PENDAHULUAN}

$\mathrm{K}$

euangan suatu negara dikelola berdasarkan kewenangan yang diatur oleh peraturan perundang-undangan. Setiap negara memiliki sejumlah lembaga yang melaksanakan kewenangan di bidang keuangan. Selain itu, setiap negara mendirikan lembaga yang kompeten dalam berurusan dengan satu hal tertentu. Salah satu contoh akan menjadi otoritas di bidang keuangan seperti Kementerian Keuangan. Mereka biasanya dibentuk oleh undang-undang khusus dan dijalankan oleh seorang menteri keuangan. Beberapa instansi dan lembaga vertikal maupun horizontal menjalankan wewenang dalam hal tertentu. Pengelolaan keuangan negara juga tidak terlepas dari tiga jenis perolehan kekuasaan. Presiden sebagai pemegang otorisasi bertindak dan berakibat pada pemasukan dan pengeluaran keuangan negara. Menteri keuangan sebagai pemegang otoritas keuangan dan Presiden adalah pemegang otoritas tertinggi. artinya disini Presiden dan menteri keuangan memperoleh kekuasaan di bidang keuangan negara secara atributif. Selanjutnya Menteri Keuangan mendelegasikan kewenangannya ke kementerian-kementerian dan pejabat-pejabat lain hingga ke pemerintah provinsi dan kabupaten/kota.

Lembaga-lembaga negara ini mempunyai kewenangan menjamin kesejahteraan rakyat. Negara-negara demokrasi menyelenggarakan kekuasaan dengan membagi kekuasaan menjadi beberapa bagian. Umumnya kekuasaan itu dibagi menjadi tiga kekuasaan utama yaitu eksekutif, legislatif, dan yudisiil. wujud nyata dari ketiganya dapat dilihat dalam bentuk lembaga-lembaga negara yang bertujuan untuk kesejahteraan rakyat. Wewenang dalam kaitan dengan otonomi daerah, diartikan hak memiliki dalam artian kekuasaan untuk mengatur sendiri (zelfregelen) dan mengelola sendiri (zelfbesturen). ${ }^{1}$

Kekuasaan pemerintahan bertumpu kepada kewenangan yang sah yang diperoleh melalui tiga sumber yaitu atribusi, delegasi, dan mandat. Atribusi merupakan wewenang untuk membuat keputusan yang langsung bersumber kepada undang-undang dalam arti materil. Tanggung jawab intern dan ekstern pelaksanaan wewenang yang didistribusikan sepenuhnya berada pada penerima wewenang. Pertanggungjawaban internal diwujudkan dalam bentuk laporan pelaksanaan kekuasaan, sedangkan pertanggungjawaban dari aspek eksternal adalah pertanggungjawaban terhadap pihak ketiga apabila dalam melaksanakan kekuasaan melahirkan derita atau kerugian bagi pihak lain., penerima wewenang bertanggunggugat atas segala akibat negatif yang ditimbulkan dalam

${ }^{1}$ Kusnardi dan harmaily Ibrahim, Pengantar hukum Tata Negara Indonesia, (Jakarta:Pusat Studi hukum Tata Negara Fakultas Hukum Universitas Indonesia,1981), h.61 
melaksanakan kekuasaan. Dalam konsep delegasi, tidak ada penciptaan wewenang dari pejabat yang satu kepada yang lainnya. Penyerahan wewenang harus dilakukan dalam bentuk peraturan hukum tertentu. Pihak yang menyerahkan wewenang disebut delegans, sedangkan pihak yang menerima wewenang disebut delegetars. Setelah delegans menyerahkan wewenang kepada delegataris, maka tanggung jawab intern dan tanggung jawab ekstern pelaksanaan wewenang, sepenuhnya berada pada delegataris.

Pada perolehan wewenang secara mandat pada dasarnya adalah suatu pelimpahan wewenang dari atasan kepada bawahan, dengan maksud untuk membuat keputusan atas nama pejabat tata usaha negara yang memberi mandat. Hal tersebut berarti bahwa keputusan yang diambil pejabat penerima mandat, pada hakikatnya merupakan keputusan dari pejabat tata usaha negara yang member mandat. Sebagai konsekuensinya, bahwa tanggung jawab dan tanggung gugat atas diterbitkannya keputusan atas dasar suatu mandat, tetap berada pada pejabat pemberi mandat. Philipus Hadjon menyatakan bahwa suatu mandat tidak diperlukan adanya ketentuan peraturan perundang-undangan yang melandasinya, karena mandat merupakan hal rutin dalam hubungan intern hirarkis dalam organisasi pemerintahan. ${ }^{2}$

Pengelolaan keuangan negara juga tidak terlepas dari tiga jenis perolehan kekuasaan di atas. Presiden sebagai pemegang otorisasi bertindak dan berakibat pada pemasukan dan pengeluaran keuangan negara. Menteri keuangan sebagai pemegang otoritas keuangan dan Presiden adalah pemegang otoritas tertinggi. ${ }^{3}$ Artinya disini Presiden dan menteri keuangan memperoleh kekuasaan di bidang keuangan negara secara atributif. Selanjutnya Menteri Keuangan mendelegasikan kewenangannya ke departemen-departemen dan pejabat-pejabat lain hingga ke pemerintah provinsi dan kabupaten/kota. Dalam hal ini lebih lanjut, pemerintah provinsi juga dapat mendelegasikan kewenangannya kepada pemerintah kabupaten/kota dalam kerangka negara kesatuan Republik Indonesia.

Pemerintahan daerah dalam menyelenggarakan urusan pemerintahan memiliki kewenangan yang telah diatur dalam Undang-Undang Nomor 23 Tahun 2014 tentang Pemerintahan Daerah (UU No. 23 Tahun 2014 tentang Pemda, kecuali urusan pemerintahan yang menjadi kewenangan mutlak Pemerintah Pusat yang ditentukan oleh undang-undang ini. Dalam Menyelenggarakan urusan

2 Murtir Jeddawi, Hukum Pemerintahan Daerah Kajian Beberapa Perda tentang Penanaman Investasi di Daerah (Yogyakarta:UII Press Yogyakarta,2006), h. 65

${ }^{3}$ Muhammad Djafar Saidi, Hukum Keuangan Negara ( Jakarta: Rajawali Pers, 2011) 
pemerintahan, pemerintahan daerah menjalankan otonomi seluas-luasnya untuk mengatur dan mengurus sendiri urusan pemerintahan berdasarkan asas otonomi dan tugas pembantuan. Terdapat urusan wajib dan urusan pilihan yang masingmasing dapat terlaksana dengan baik jika didukung oleh anggaran yang memadai. Sebagaimana kita ketahui bahwa dalam membiayai urusan pemerintahan daerah, anggaran pembiayaannya dibiayai oleh daerah sendiri melalui sumber-sumber penerimaan diantaranya bersumber dari pendapatan asli daerah (PAD), Dana perimbangan, dan lain-lain pendapatan yang sah. Permasalahan sumber-sumber penerimaan daerah tersebut seringkali dijumpai dalam prakteknya utamanya alokasi penerimaan dan pengeluarannya.

Permasalahan dana perimbangan yang menjadi sumber penerimaan potensial bagi daerah berhubungan erat dengan pembagian urusan pemerintahan pusat dan daerah karena dananya bersumber dari APBN. Dana Perimbangan adalah dana yang bersumber dari pendapatan APBN yang dialokasikan kepada daerah untuk mendanai kebutuhan daerah dalam rangka pelaksanaan desentralisasi. Menurut Peraturan Pemerintah Nomor 55 Tahun 2005, Dana Perimbangan terdiri atas Dana Bagi Hasil (DBH), Dana Alokasi Umum (DAU) dan Dana Alokasi Khusus (DAK). Dana perimbangan tersebut dibentuk untuk mendukung pendanaan program otonomi.

Dana Bagi Hasil merupakan dana perimbangan yang strategis bagi daerahdaerah yang memiliki sumber-sumber penerimaan pusat di daerahnya, meliputi penerimaan pajak pusat yaitu pajak penghasilan perseorangan $(\mathrm{PPh}$ perseorangan), Pajak Bumi dan Bangunan (PBB), Bea Perolehan Hak atas Tanah dan Bangunan (BPHTB), dan penerimaan dari sumber daya alam (Minyak Bumi, Gas Alam, Pertambangan Umum, Kehutanan dan Perikanan).

DAU bertujuan untuk pemerataan kemampuan keuangan antar-daerah yang dimaksudkan untuk mengurangi ketimpangan kemampuan keuangan antardaerah melalui penerapan formula yang mempertimbangkan kebutuhan dan potensi daerah. DAU suatu daerah ditentukan atas besar kecilnya celah fiskal (fiscal gap) suatu daerah, yang merupakan selisih antara kebutuhan daerah (fiscal need) dan potensi daerah (fiscal capacity). Alokasi DAU bagi daerah yang potensi fiskalnya besar tetapi kebutuhan fiskal kecil akan memperoleh alokasi DAU relatif kecil. Sebaliknya, daerah yang potensi fiskalnya kecil, namun kebutuhan fiskal besar akan memperoleh alokasi DAU relatif besar. Secara implisit, prinsip tersebut menegaskan fungsi DAU sebagai faktor pemerataan kapasitas fiskal.

DAK dimaksudkan untuk membantu membiayai kegiatan-kegiatan khusus pada daerah tertentu yang merupakan urusan daerah dan sesuai dengan prioritas 
nasional, khususnya untuk membiayai kebutuhan sarana dan prasarana pelayanan dasar masyarakat yang belum mencapai standar tertentu atau untuk mendorong percepatan pembangunan daerah.

\section{PEMBAHASAN}

Beberapa permasalahan timbul dalam aspek dana perimbangan sering menjadi temuan pemeriksaan. Pokok-pokok permasalahan terkait pola alokasi dipaparkan secara jelas dalam Grand Desaign Desentralisasi Fiskal Indonesia, yaitu terletak pada formula alokasi $\mathrm{DBH}$, dasar nilai penetapan bagi hasil, pemanfaatan DBH di daerah, serta mekanisme penyaluran DBH di daerah.

Formula alokasi DBH saat ini terlalu komplek dan kurang memiliki landasan yang kuat. Rumusan bagi hasil untuk setiap jenis pajak dan juga penerimaan sumber daya alam sangat bervariasi satu dengan yang lain, dan terkadang dalam perumusan alokasi ini tidak ada argumentasi yang jelas tentang formula bagi hasil tersebut. Formula DBH menjadi makin kompleks lagi karena pemberlakuan formula yang berbeda untuk daerah-daerah dengan fasilitas otonomi khusus, yaitu Nanggroe Aceh Darussalam dan Papua.

Kerumitan lain dari alokasi DBH adalah beragamnya dasar penetapan untuk bagi hasil. Dana bagi hasil minyak dan gas bumi kepada daerah didasarkan pada nilai net-operating income setelah dikurangi berbagai jenis pajak ( $\mathrm{PPh}, \mathrm{PPN}$, dan PBB). Formula yang berbeda untuk minyak bumi dan gas alam. Sedangkan untuk Pertambangan, Kehutanan dan Perikanan, nilai yang dibagihasilkan pada dasarnya ada dua jenis yaitu biaya sewa perijinan usaha dan royalti untuk produksi yang dihasilkan.

Pemanfaatan DBH juga ditengarai belum jelas di daerah, bahkan terkadang terjadi tumpang tindih program kegiatan antara Provinsi dan Kabupaten/Kota, misalnya pembangunan lapangan udara pada lokasi yang berdekatan dengan anggaran berbeda, yaitu dari provinsi dan yang satunya dari kabupaten.

Permasalahan klasik yang terus terjadi sampai dengan sekarang adalah mekanisme penyaluran DBH di daerah, yaitu keterlambatan penyaluran DBH ke daerah, khususnya untuk DBH yang berasal dari sumber daya alam. Seharusnya penyaluran dilakukan pada setiap akhir kuartal, dimana nilai yang disalurkan pada 3 kuartal pertama adalah nilai yang didasarkan kepada angka yang disepakati di APBN, sedangkan nilai yang disalurkan pada kuartal terakhir sudah memperhitungkan berbagai penyesuaian terhadap realisasi yang terjadi. Jumlah 
yang bisa dibagihasilkan untuk realisasi minyak dan gas bumi adalah maksimum $130 \%$ dari harga asumsi awal di APBN.

Fenomena lain yang terjadi yaitu beberapa daerah yang telah menetapkan RPJMD telah ditetapkan dengan Peraturan. Perwujudan visi daerah telah dilaksanakan oleh Pemerintah Kabupaten/Kota dan DPRD Kabupaten/Kota. Sementara itu dalam pengelolaan keuangannya, Pemerintah Kabupaten/Kota belum menyusun Peraturan Daerah tentang Pokok-Pokok Pengelolaan Keuangan Daerah sehingga Keputusan Kepala Daerah tentang sistem dan prosedur Pengelolaan Keuangan Daerah juga belum ada. Penyusunan dan penyajian Laporan Keuangan Pemerintah Kabupaten/Kota biasanya dilakukan oleh Bagian Keuangan pada Sekretariat Daerah yang struktur organisasinya dibentuk berdasarkan Peraturan Daerah tentang Susunan Organisasi dan Tata Kerja Sekretariat Daerah.

Secara terinci permasalahan mengenai dana perimbangan dalam mewujudkan terciptanya kemandirian daerah yaitu :

1. Rumitnya formula alokasi dana perimbangan terhadap proporsi pembagian DBH antara pusat dan daerah.

2. Alokasi dana perimbangan belum disalurkan lebih baik, agar alokasi ke daerah penghasil menjadi tepat waktu dan tepat jumlah, sehingga dana tersebut dapat dimanfaatkan secara optimal sesuai dengan yang direncanakan.

3. Tidak jelasnya alokasi DBH misalnya dengan penetapan persentase tertentu dari DBH untuk dapat dimanfaatkan bagi pengembangan bidangbidang tertentu contohnya: pendidikan, kesehatan ataupun perbaikan lingkungan hidup di daerah.

Salah satu contoh pengembangan alokasi DBH untuk bidang tertentu yaitu di bidang kehutanan. Menteri keuangan dalam melaksanakan ketentuan Pasal 27 ayat (5) Peraturan Pemerintah Nomor 55 Tahun 2005 tentang Dana Perimbangan). Menteri Keuangan menetapkan perkiraan alokasi DBH Sumber Daya Alam untuk masing-masing daerah paling lambat 30 (tiga puluh) hari setelah diterimanya ketetapan dari menteri teknis. Menteri Keuangan perlu menetapkan Peraturan Menteri Keuangan tentang Penetapan Perkiraan Alokasi Dana Bagi Hasil Sumber Daya Alam Kehutanan pada suatu Tahun Anggaran.

Di samping itu, Kurangnya perhatian Pemerintah Pusat terhadap Sistem Pengendalian Intern yang baik melalui penetapan peraturan. Banyaknya keluhan Pemda karena keterlambatan penyaluran DBH SDA tidak ditanggapi secara baik yang seharusnya dilakukan diantaranya dengan perbaikan sistem penyaluran DBH 
SDA dan pengendalian dan pengawasan Kepala Daerah selaku Pemegang Kekuasaan Umum Pengelola Keuangan Daerah belum berjalan sebagaimana mestinya.

Setiap negara harusnya mempunyai konsep kewenangan yang jelas. Penegasan ini menghindari konflik berkepanjangan saling klaim kewenangan antara lembaga negara yang satu dengan lainnya atau kewenangan urusan pemerintah pusat, pemerintah provinsi, dan pemerintah kabupaten/kota seperti yang dikenal di Negara Kesatuan Republik Indonesia. Setelah usaha mengantisipasi terjadinya konflik tersebut, selanjutnya penegakan dan perlindungan hukum diharapkan dapat terwujud.

Negara mempunyai kekuasaan sangat besar untuk mengatur rakyat dengan berbagai cara demi kesejahteraan rakyat. Bahkan, dengan cara-cara kekerasan (melakukan penangkapan, penahanan, penggusuran) selama dalam batas kewenangan dapat dikategorikan sebagai bentuk legal perbuatan negara. Dengan kata lain, kedaulatan negara dipersamakan dengan monopoli negara terhadap rakyat baik fisik maupun materi. Monopoli fisik tersebut sejalan dengan pandangan Max Weber tentang bagaimana hubungan negara dengan monopoli tersebut. Dia menyatakan bahwa hal itu disebabkan karena negara ini mempunyai monopoli atau kekuasaan penuh dalam menggunakan kekuasaan fisik. Akan tetapi, negara (state) tidak dapat menjalankan kedaulatannya tanpa adanya pemerintah sebagai representasi negara berhubung negara dalam keadaan statis.

Untuk memeriksa tanggung jawab di bidang keuangan negara maka diadakanlah Badan Pengawas Keuangan Negara yang fungsi utamanya melakukan pemeriksaan keuangan terhadap Anggaran Pendapatan dan Belanja Negara (APBN) dan Anggaran Pendapatan dan Belanja Daerah (APBD). pada zaman orde baru, di bentuk sejumlah badan atau institusi yang berkaitan dengan pengawasan di bidang keuangan seperti Badan Pemeriksa Keuangan dan Pembagunan (BPKP) dan sejumlah inspektorat yang melekat disetiap lembaga departemen dan non-departemen, begitu pula didaerah terdapat sejumlah inspektorat yang merupakan instansi vertikal yang bernaung di bawah departemen keuangan.

Suatu anggaran seharusnya difungsikan sebagai alat perencanaan sektor publik yaitu untuk merencanakan tindakan apa yang akan dilakukan oleh pemerintah, berapa biaya yang dibutuhkan, dan berapa hasil yang diperoleh dari belanja pemerintah tersebut dan merupakan alat koordinasi antar bagian dalam pemerintahan. Disamping itu, anggaran publik juga berfungsi sebagai alat komunikasi antar unit kerja dalam lingkungan eksekutif. 
Apkasi menyatakan ada 21 masalah dalam proses transfer dana pemerintah pusat ke pemerintah daerah yang mengganggu pelaksanaan pembangunan. ${ }^{4} \mathrm{Hal}$ ini mengindikasikan bahwa terdapat permasalahan yang kompleks pada proses transfer dana Pusat ke pemerintah daerah. Sebenarnya masih terdapat beberapa jenis dana yang ditransfer oleh Pusat selain DBH, DAK dan DAU yaitu bentuk Dana Bagi Hasil Sumber Daya Alam (DBH SDA), Dana Penyesuaian, Dana Insentif Daerah (DID), dan Dana Percepatan Pembangunan Infrastruktur Daerah (DPPID). Namun, DBH, DAK, dan DAU ini yang paling banyak menjadi sorotan mengingat besaran dan persebarannya meliputi seluruh wilayah Indonesia. Proses penyaluran dana tersebut masih berbenturan dengan keinginan pusat yang belum sepenuhnya percaya kepada kemampuan pemerintah daerah untuk mengelola keuangannya sementara dana yang berasal dari Pendapatan Asli Daerah (PAD) yang dipungut dan dipergunakan oleh pemerintah daerah masih belum memadai.

Tumpang tindih urusan pemerintahan antara Pusat dan Pemerintah daerah memang belum sepenuhnya selesai. Ada gap yang pasti nampak antara pembagian urusan pemerintahan dalam negara kesatuan seperti Indonesia. Namun, semua bisa dikembalikan kepada asas-asas umum pemerintahan yang baik seperti adanya transparansi keuangan oleh pusat kepada daerah. Disamping itu, perangkat peraturan perundang-undangan juga belum mampu menopang kejelasan dan ketegasan proses penyaluran dana pusat kepada daerah. Pada konsep negara hukum dikenal adanya jaminan hukum bagi rakyat terhadap kekuasaan pemerintahan yang diwujudkan melalui 4 (empat) substansi pokok. Pertama, asas legalitas, dalam penyaluran dana pusat kepada daerah, ada tiga hal pokok yang harus diperhatikan yaitu kewenangan, prosedur, dan substansi. Kemudian perlindungan hak-hak dasar dan pembagian kekuasaan di bidang pemerintahan melalui desentralisasi fungsional dan territorial serta pengawasan oleh badan peradilan melalui prinsip independen, impartial, non-discrimination.

Demikianlah arti pentingnya pengelolaan dana perimbangan guna mendukung penyelenggaraan pemerintahan daerah yang tetap memperhatikan pembagian urusan pemerintahan pusat dan daerah. Permasalahan yang terjadi sedikit banyak dipengaruhi oleh rentang kendali yang terlalu jauh antara pemerintah pusat dan daerah, sementara pendanaan untuk pembiayaan kepentingan daerah sangat dibutuhkan segera. Selain itu, penegakan dan perlindungan hukum akibat dari perbuatan pemerintah termasuk di bidang keuangan negara harus bermuara pada kesejahteraan masyarakat dan menjadi tugas dari negara untuk mewujudkannya.

${ }^{4}$ www.bisnis.com, diakses pada 20/11/2017 


\section{PENUTUP}

Permasalahan dana perimbangan yang menjadi sumber penerimaan potensial bagi daerah berhubungan erat dengan pembagian urusan pemerintahan pusat dan daerah karena dananya bersumber dari APBN. Dana Perimbangan adalah dana yang bersumber dari pendapatan APBN yang dialokasikan kepada daerah untuk mendanai kebutuhan daerah dalam rangka pelaksanaan desentralisasi berupa Dana Bagi Hasil (DBH). Dana Bagi Hasil itu sendiri merupakan dana perimbangan yang strategis bagi daerah-daerah yang memiliki sumber-sumber penerimaan pusat di daerahnya. Kewenangan dalam pengelolaan dana perimbangan adalah presiden dan menteri keuangan sebagai pemegang otoritas pelaksana atas nama presiden. Menteri keuangan mendelegasikan kewenangannya kepada departemen-departemen dan pejabat di daerah. Muara dari penegakan dan perlindungan hukum akibat dari perbuatan pemerintah termasuk di bidang keuangan negara harus bermuara pada kesejahteraan masyarakat dan menjadi tugas dari negara untuk mewujudkannya. 


\section{DAFTAR PUSTAKA}

Kusnardi dan harmaily Ibrahim, 1981, Pengantar hukum Tata Negara Indonesia, Jakarta:Pusat Studi hukum Tata Negara Fakultas Hukum Universitas Indonesia

Murtir Jeddawi, 2006, Hukum Pemerintahan Daerah Kajian Beberapa Perda tentang Penanaman Investasi di Daerah, Yogyakarta:UII Press Yogyakarta

Muhammad Djafar Saidi, 2011, Hukum Keuangan Negara, Jakarta: Rajawali Pers www.bisnis.com, diakses pada 20/11/2017 